After the Black Death 
THE MIDDLE AGES SERIES

Ruth Mazo Karras, Series Editor

Edward Peters, Founding Editor

A complete list of books in the series is available from the publisher. 


\section{After the Black Death}

Plague and Commemoration Among Iberian Jews

\section{Susan L. Einbinder}


Copyright (C) 2018 University of Pennsylvania Press

All rights reserved. Except for brief quotations used for purposes of review or scholarly citation, none of this book may be reproduced in any form by any means without written permission from the publisher.

Published by

University of Pennsylvania Press

Philadelphia, Pennsylvania I9IO4-4II2

www.upenn.edu/pennpress

Printed in the United States of America on acid-free paper IO 9877654322 I

Library of Congress Cataloging-in-Publication Data

Names: Einbinder, Susan L., 1954- author.

Title: After the Black Death : plague and commemoration among Iberian Jews / Susan L. Einbinder.

Other titles: Middle Ages series.

Description: Ist edition. | Philadelphia : University of Pennsylvania Press, [2018] | Series: The Middle Ages series | Includes bibliographical references and index.

Identifiers: LCCN 201705166I | ISBN 97808I2250312 (hardcover : alk. paper)

Subjects: LCSH: Black Death—Iberian Peninsula—Religious aspects_-Jews. | Black Death_Iberian Peninsula_Religious aspects_-Judaism. | Jews_-Iberian Peninsula-History. | Antisemitism-Iberian Peninsula-History-To I500. | Jewish literature-Iberian Peninsula-History-To I500.

Classification: LCC RCi78.S7 E46 20I8 | DDC 616.9/2320899240366-dc23

LC record available at https://lccn.loc.gov/201705I66I 